\title{
Measurement of Hydrogen Fuel Cell Car using MEMS Sensor
}

\author{
Mohanraj, Hemalatha.B.G, Sowmiya Manoj.
}

\begin{abstract}
In today's world, with increasing price of fuels, depletion of natural resources and pollution levels mounting up, an eco friendly and cheap alternative fuel in automobiles can be implemented. A hydrogen fuel cell makes it possible by converting the hydrogen to electricity that powers the vehicle. The proposed green fuel is hydrogen which is combined with oxygen inside the fuel cell. The byproduct is water which can be used for purposes like irrigation, domestic and industrial uses after treatment. The fuel cell efficiency is dependent on its moisture content and so a MEMS based humidity sensor is proposed for measuring the humidity
\end{abstract}

Keywords : Fuel cell, MEMS, humidity, COMSOL.

\section{INTRODUCTION}

A hydrogen hybrid car is one which does not require any fuel source like petrol, diesel, CNG, LPG or any such non-renewable resources to run. The basic working of the car is such that the hydrogen is the simplest and the most abundant element in the universe. Although the cars are related to more a kind of science fiction but the fact that hydrogen has been used to render and generate many energy resources. With steam upcoming out of the exhausts as a replacement for the foul smelling gases it is the ideal fuel. Here hydrogen is the most copious element of the universe, represent about approximately $90 \%$ of atoms in authenticity.[1-10]

It consists of a 1 electron and a proton. The fuel cell generate the electricity by strip an electrons commencing the protons and the electrons to generate a pure brook of electricity. The ionized hydrogen atoms coalesce through oxygen to outward appearance water. The new product of these process is heat. The fact that the kind of resources can be utilized to the fullest and used on such a large scale that each of the natural resources on earth can be utilized properly and can also be balanced leading to its use in future generations.[11][12][13]

\section{II.WORKING:}

The hydrogen fuel cell will operates comparable to the battery. The basic working of the car is such that the hydrogen is the simplest and the most abundant element in the universe. Where has here there are two electrodes, an anode and a

Revised Manuscript Received on August 22, 2019.

Mohanraj Assistant Professor, Department of Electronics And Communication Engineering,, Bharath Institute of Higher Education and Research, Chennai, India. dspmohanraj@gmail.com

Hemalatha.B, Assistant Professor, Department of Electronics And Communication Engineering,, Bharath Institute of Higher Education and Research, Chennai, India. contacthemab@gmail.com

Sowmiya Manoj, , Assistant Professor, Department of Electronics And Communication Engineering,, Bharath Institute of Higher Education and Research, Chennai, India. sow_anu@yahoo.com cathode, that will be divided by its own membrane. Oxygen may be passed above one electrode and hydrogen passes over to the other electrode. The hydrogen which may react to a catalyst over that electrode anode and that it converts the hydrogen gas into the negatively charged electrons (e-) and the positively charged ions $(\mathrm{H}+)$. The electrons which flow away of the cell to be used as electrical energy as shown in figure 1.0. The hydrogen ions move through the electrolyte of the membrane to the cathode electrode that they come together with oxygen and the electrons to produce water. Thus, the main advantage of the kind of fuel cells is that they do not run out.[14][15]

Here the $80 \%$ efficient of Fuel cells will get two or three epoch extra energy from the out of hydrogen which is customary customized car engine. Due to the internal burning engine has a stage where you generate a lot of heat and this is where a lot of energy is exhausted, and where the efficiency decreases. Although the cars are related to more a kind of science fiction but the fact that hydrogen has been used to render and generate many energy resources. Major ways to store hydrogen in the car-of-the-future. First method is hydrogen gas can be rehabilitated to a liquid, but that bud vase has to be well-built to a temperature of about $2600 \mathrm{C}$ below zero. [16]

In this manner the vehicle is fueled by an electrical motor with power being delivered on-board as it were. The power device is coupled to a hydrogen tank, a battery and furthermore to an inverter. At the point when the motor is begun or driven in city the electrical motor is controlled by the battery, at that point the energy units begin creating on board power with hydrogen. A major favorable position amid this procedure is that the battery will likewise energize the power module.

At the point when more power is required the vehicle draws power at the same time from both energy unit and battery. Vitality improved amid braking is changed into power with the assistance of the inverter and is given to revive the battery. The hydrogen powered car's performance is equivalent to that of a normal fuel cell car. $5 \mathrm{~kg}$ of hydrogen at 700

\section{III.DESIGN OF MICRO HUMIDITY SENSOR:}

Water is an important by product of a fuel cell, its moisture content must be taken care of, in order to improve its efficiency. Conventional methods use humidity probes which are externally mounted to measure the humidity the difference in the levels of humidity is utilized to calculate the relative humidity $(\% \mathrm{RH})$. The proposed method is to implement a micro humidity sensor inside the fuel cell and thereby get an accurate and continuous measure of $\% \mathrm{RH}$.

The humidity is measured using capacitive principle and the capacitance can also be converted into a voltage output. The humidity sensor is bar pressure is enough to run 


\section{Measurement of Hydrogen Fuel Cell Car Using MEMS Sensor}

the car to about 500 kilometers and we know that it is silent and non- polluting as it only gives out water and unused gas.

Electric Current

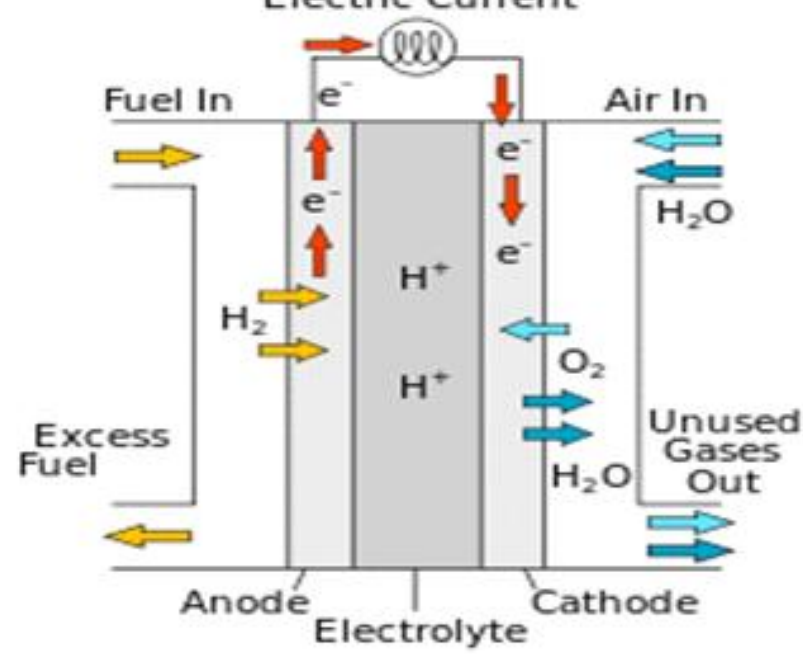

Fig 1.Working of a fuel cell fabricated by following method.

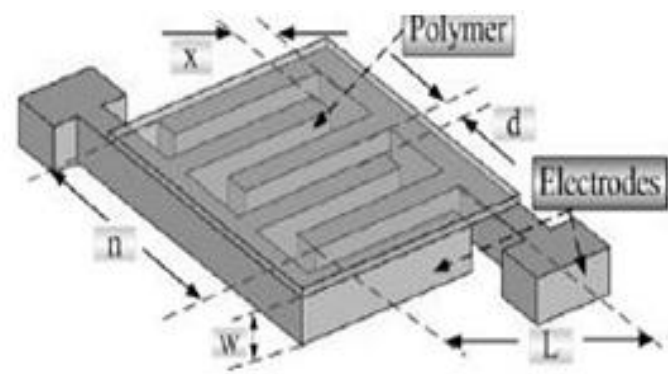

Fig.2 The Structure of humidity sensor with interdiginated, electrodes.

A thin film of polyimide is coated on the Si substrate and the electrode assembly is carefully places inside the fuel cell chamber. When the polyimide material absorbs the moisture, it swells and. Humidity sensor can be expressed by an equation

$\mathrm{C}=2 \mathrm{n} \varepsilon \mathrm{W}(\mathrm{L}-\mathrm{x}) / \mathrm{d}$

The structure of capacitive type humidity sensor $\mathrm{s}$ is shown in figure 1.1

\section{IV.SIMULATION:}

The simulation was carried out in COMSOL Multiphysics and the humidity sensor for demonstration was designed as a beam fixed at one end and free at the other end. The polyimide layer is coated on top of the substrate and water droplets were designed in a semi-circular shape and the testing was carried out as shown in figure 1.2

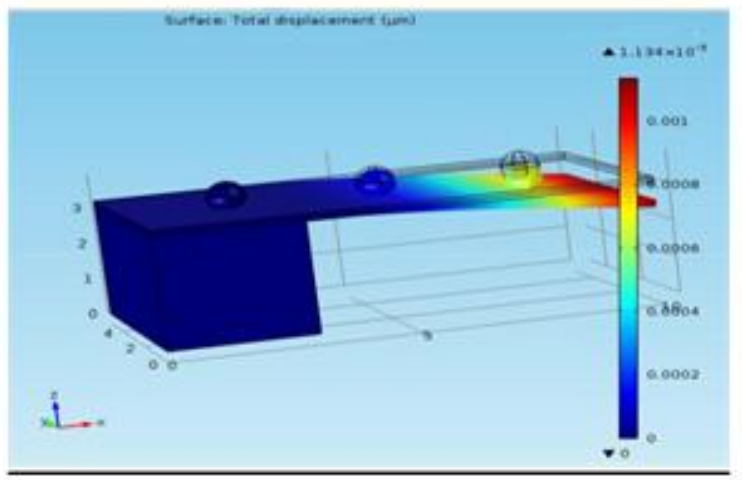

\section{V.DISTRIBUTION INFRASTRUCTURE:}

Hydrogen siphons have been added to existing petroleum stations, where at first look they seem much equivalent to common siphons. Since the hydrogen utilized as a compacted gas, filling the tank isn't only a material of putting a spout in the oil tank pit and let the gravity deal with the rest. As a swap for, a tight seal has been built up between the spout and vehicle, and powerful siphons need to constrain hydrogen through the spout until the most needed weight is come to. By and by, the current-age hydrogen siphons are as of now simple and safe satisfactory for a normal purchaser to utilize.

Hydrogen half and halves consolidate the high efficiency qualities of nowaday's a fuel electric cross breeds with the almost zero emanations of inner burning motors running on hydrogen. The outcome is a truly spotless running vehicle, utilizing the equivalent ecological positive hydrogen energy component vehicles, however at a lower cost. A recently created strong capacity mechanism for hydrogen vehicles is critical to this proficient innovation. All things considered, there's a great deal of work ahead to make this vision adequate costs must descend, power device sturdiness must improve, and difficulties that leave from the vehicles themselves must be met.[17-20]

\section{VI.CONCLUSION}

The MEMS based sensor is more accurate and convenient to measure the moisture content when compared to conventional counterparts because of the following reasons: in situ measurement, improved sensitivity, better reliability and stability. The following factors have to be considered as precautionary measures in order to have an effective humidity measurement: Packaging and lead wire connections.

\section{REFERENCES}

1. Kongkham, D. \& Sundararajan, M. 2019, "Distributed wideband sensing method for faded dynamic spectrum access", International Journal of Innovative Technology and Exploring Engineering, vol. 8, no. 10, pp. 4309-4312.

2. Balaji, S., John Paul Praveen, A. \& Mohanraj, R. 2019, "Recognizable proof and analysis of palm print in biometric authentication system using bayes techniques", International Journal of Innovative Technology and Exploring Engineering, vol. 8, no. 9 Special Issue 3, pp. 1126-1129. 3. Kavitha, G., Priya, N., Velvizhi, R. \& Allin Geo, A.V. 2019, "Parallel computation in correspondence and signal processing", International Journal of Innovative Technology and Exploring Engineering, vol. 8, no. 9 Special Issue 3, pp. 1136-1139.

4. Hema, R., Sundararajan, M. \& Balaji, S. 2019, "Smartphone control robot with automatic firing gun", International Journal of Innovative Technology and Exploring Engineering, vol. 8, no. 9 Special Issue 3, pp 625-627.

5. Kaliyamurthie, K.P., Sundar Raj, B., Velvizhi, R. \& Shanmugapriya, K. 2019, "Dual band paper substrate CPW antenna for wireless applications", International Journal of Innovative Technology and Exploring Engineering, vol. 8, no. 9 Special Issue 3, pp. 605-608.

6. Geo, A.V.A., Arunachalam, A.R., Michael, G. \& Elankavi, R. 2019, "Evaluating architecture using compact modalities", International Journal of Innovative Technology and Exploring Engineering, vol. 8, no. 9 Special Issue 3, pp. 836-838.

7. Theivasigamani, S., Jeyapriya, D. \& Anita Davamani, K. 2019, "Anamoly analyzing and exploring for wireless sensor networks", International Journal of Innovative Technology and Exploring Engineering, vol. 8, no. 9 Special Issue 3, pp. 1116-1118.

8. Jeyapriya, D., Theivasigamani, S., Velvizhi, R. \& Nandhini, P. 2019 "Program detection in wireless feeler networks", International Journal of Innovative Technology and Exploring 
Engineering, vol. 8, no. 9 Special Issue 3, pp. 1194-1195.

9. Gowri Sankaran, B., Karthik, B. \& Vijayaragavan, S.P. 2019, "Image compression utilizing wavelet transform", International Journal of Innovative Technology and Exploring Engineering, vol. 8, no. 10, pp. 4305-4308.

10. Gowri Sankaran, B., Karthik, B. \& Vijayaragavan, S.P. 2019, "Weight ward change region plummeting change for square based image huffman coding", International Journal of Innovative Technology and Exploring Engineering, vol. 8, no. 10, pp. 4313-4316.

11. Hema, R., Sundararajan, M. \& Balaji, S. 2019, "Smartphone control robot with automatic firing gun", International Journal of Innovative Technology and Exploring Engineering, vol. 8, no. 9 Special Issue 3, pp. 625-627.

12. Rangaswamy, K. \& Rajabhushanam, C. 2019, "Congestion control in wireless network using TCP friendly rate control (TFRC)", International Journal of Recent Technology and Engineering, vol. 8, no. 2 Special issue 3, pp. 1598-1602.

13. Tamil Selvan, S. \& Sundararajan, M. 2019, "Performance Parameters of 3 Value 8t Cntfet Based Sram Cell Design Using H-Spice", International Journal of Recent Technology and Engineering, vol. 8, no. 2 Special issue 5, pp. 22-27.

14. Vinoth, V.V. \& Kanniga, E. 2019, "Steganographical techniques in hiding text images - system", International Journal of Recent Technology and Engineering, vol. 8, no. 2, pp. 6535-6537.

15. Saravana, S., Balaji, S., Arulselvi, S. \& John Paul Praveen, A. 2019, "Reliable power quality monitoring and protection system", International Journal of Innovative Technology and Exploring Engineering, vol. 8, no. 9 Special Issue 3, pp. 644-645.

16. Sundaramoorthy, A. \& John Wiselin, M.C. 2019, "Single patch antenna with multiple feed", International Journal of Innovative Technology and Exploring Engineering, vol. 8, no. 9, pp. 1743-1747.

17. Velavan, R., Bharanidharan, S. \& Sheeba, B. 2019, "EMF pollution Causes, effects and protection", International Journal of Innovative Technology and Exploring Engineering, vol. 8, no. 9 Special Issue 3, pp. 1166-1168.

18. Veer, R.A., Arulselvi, S. \& Karthik, B. 2019, "Construction of ensemble square classification approaches in MIMO OFDM", International Journal of Engineering and Advanced Technology, vol. 8, no. 5, pp. 2039-2041.

19. Agitha, W. \& Kaliyamurthie, K.P. 2019, "Improved energy efficient in WBAN using MAC with cloud computing", International Journal of Innovative Technology and Exploring Engineering, vol. 8, no. 8, pp. 2405-2408.

20. Kastro, G.G. \& Wiselin, M.C.J. 2019, "Design and analysis of stub loaded resonator", International Journal of Recent Technology and Engineering, vol. 8, no. 1 Special Issue4, pp. 272-283.

\section{AUTHORS PROFILE}

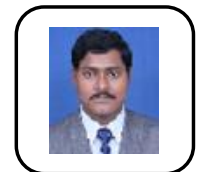

Mohanraj Assistant Professor, Department of Electronics And Communication Engineering,, Bharath Institute of Higher Education and Research, Chennai, India.

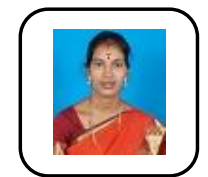

Hemalatha.B, Assistant Professor, Department of Electronics And Communication Engineering,, Bharath Institute of Higher Education and Research, Chennai, India.

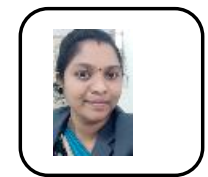

Sowmiya Manoj, , Assistant Professor, Department of Electronics And Communication Engineering, Bharath Institute of Higher Education and Research, Chennai, India.. 